\title{
Addressing Offers with Apparently Unusual Low Prices
}

\author{
Andrei Mirel FLOREA ${ }^{\star}$, Riana Iren RADU ${ }^{\star \star}$, Silvius STANCIU ${ }^{\star \star \star}$
}

\begin{tabular}{l}
\hline \multicolumn{1}{c}{ A R T I C L E I N F O } \\
\hline Article history: \\
Accepted November 2019 \\
Available online December 2019 \\
\hline JEL Classification \\
H57, L80, M21 \\
Keywords: \\
Price, Public procurement, Services
\end{tabular}

\section{Introduction}

Public Procurement represents the supply of goods and services performed by Public Authorities (Rolfstam et al., 2013). But the implications of Public Procurement on a country's economy are multiple. One of these implications is represented by stimulation of innovation, by influencing the economic agents in the production and trade of products, services and new technologies (Edler et. al., 2006).

Considering the fact that the level of Public Procurement in 2018 represents $15 \%$ of the Gross Domestic Product (GDP), the importance of public money management is vital. The effects of some inadequate procurement procedure reflects upon the Contracting Authority and upon population, environment, social and economic relations at micro and macroeconomic level (Vargo et al., 2017).

In the present scientific endeavor we plan on doing an analysis of the procurement process stages which can lead to the tendering below market level of services.

In the first part of the paper, the key stages that influence the price of the contracted services have been presented in a theoretical way, trying to establish a series of good practices that should be followed in order to avoid altering the quality of services and inefficient spending of public money. Likewise, during the presentation of the procurement process stages, a risk analysis on a scale from 1 to 5 for the selection and evaluation process was performed. The purpose of the analysis is to identify the main generating factors of the misunderstanding of the services requested by the Contracting Authority.

An empirical analysis has been performed in the second part of the paper, analysis performed on the Public Procurement Contracts for financial audit services which deal with the auditing of projects with European financing in the first semester of the year 2019.

The importance of the study is generated by the influence of the tender's low value for the audit services on the quality of the verifications performed by the auditor. At the same time, there were identified significant differences between the estimated value of the procurement and the assigned value, in the context of personnel, transport, accommodation etc. costs increasing.

\section{Good practices for an optimum development of public service procurement procedure}

In the context of Romania's integration into the European Union (EU), the Public Procurement sector had to reorganize itself in order to comply with the principles imposed by European law. In general, the EU encourages the competition between operators, advocating for the elimination of discrimination and preferential treatment.

Another important factor is the transparency of the procurement process that aims to ensure the publication of information in order to eliminate any doubt on discriminatory treatment and to respect the integrity of the procedure. 
At the same time, the identification of the optimum situation by which the objective of the procurement is fulfilled, without leading to faulty usage of the public money and keeping an equivalent / over-unity quality - price report.

\subsection{The selection process}

According to Directive 2004/18/EC, as well as to the national legislation, 6 stages within any Public Procurement have to be followed. These were presented within Figure 1. The main stages in the selection process were highlighted in the upper part of the figure and the stages of the assessment process were highlighted below them.

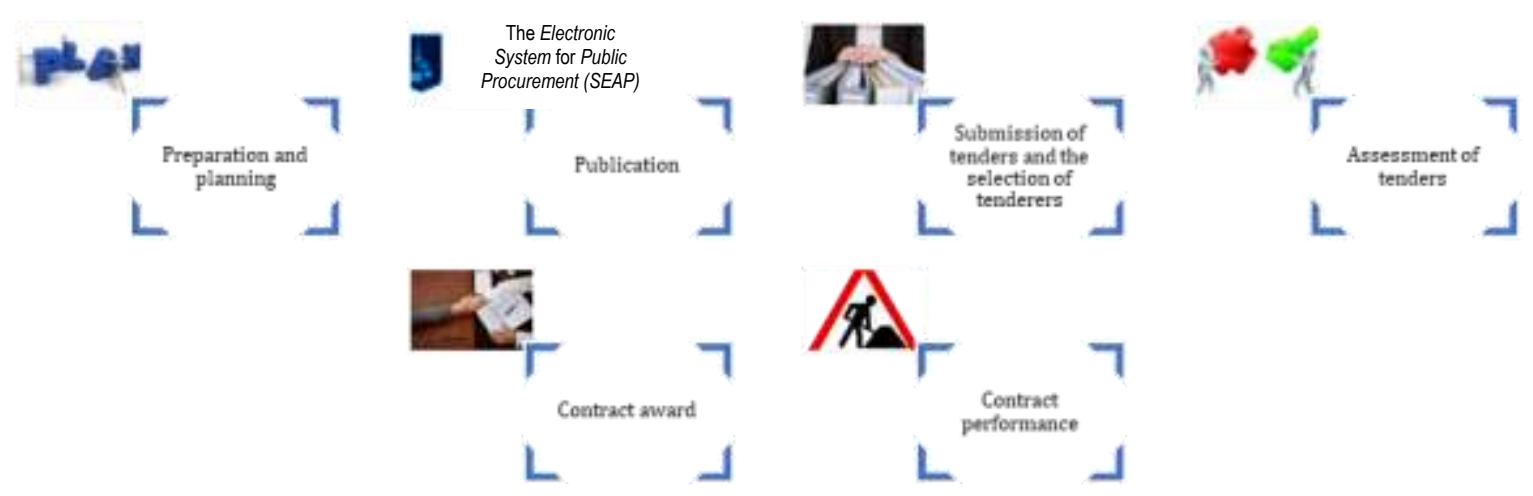

Figure 1. The mandatory stages within Public Procurement

Source: Issued by the author

In the author's opinion, the preparation and planning stage is the most important stage, influencing the development of the entire procurement. concluded.

The duration of this stage is determined by the complexity of the contract which is going to be

It is important to understand the need for procurement, the necessary characteristics which must be fulfilled and how this need can be satisfied. The definition of a budget according to the reality registered on the market, as well as the definition of some minimum qualitative indicators represents also a stage within the preparation process. (Word Bank, 2016)

The preparation supposes at the same time the identification of suppliers which are interested in participating to the respective procurement (Woldesenbet and Worthington, 2019). Public consultation is performed in order to establish a competitive estimative price, which would also comply with the average price practiced at market level.

The pulse of the market is determined during the public consultation, but at the same time the economic operators can make observations on possible omissions or expressions that can create confusion.

Failure to organize this consultation may result in considerable costs in the event of subsequent observance of non-compliance and may lead to the resumption of the tender, the delay of the works, the loss of funding, etc. (Word Bank, 2016)

The Public Procurement specialist should be careful that the observations made during the public consultation are not likely to affect competition, to generate conflicts of interest or to distort the smooth running of the process. Discussions with a procurement specialist from the internal department regarding issues resulting from the public consultation ensure an increased level of security.

All the stages presented previously that dealt with the preparation were aimed at understanding the need for procurement and the resources that must be involved to satisfy it. After that, it is necessary to establish the object of the contract and whether it is a single work (Article 1, paragraph 2 of Directive $2004 / 18$ / EC) or it must be divided into several lots. It is necessary to create a timetable of the entire procedure, in which to include time for all obstacles that may occur in a manner contrary to optimism.

Depending on the complexity of the project, staff is allocated both from the unit and from outside it, if their expertise is necessary to contribute to the successful completion of the acquisition. The appointment of an Evaluation Committee with solid competences and knowledge in the field of procurement can add value and lead to the exact purchase of the necessary service at optimal parameters.

In order to justify the completion of all the necessary steps, it is necessary to establish a database with documents that allow the authority to have a record of the procedure performed.

Another important step in the planning process is represented by the choice of the optimal procurement procedure to be carried out without affecting transparency and competition. The main types of procedures were presented in Figure 2. 


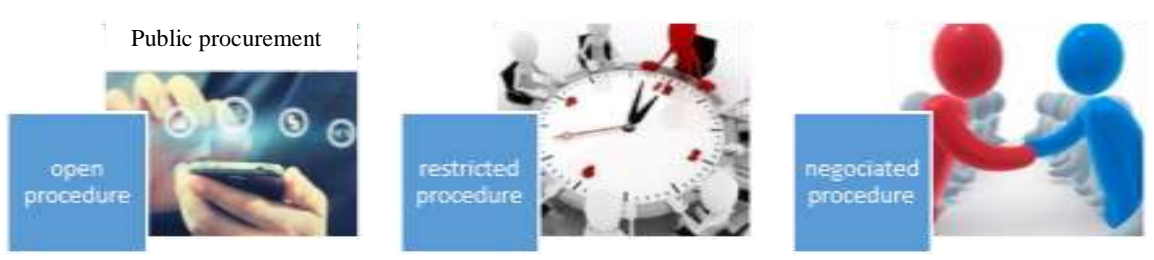

Figure 2. Types of procedures

Source: processed by the author based on the Guide on Public Procurement published by the European Commission

Each procedure has its advantages and disadvantages. The open procedure is usually the most used as it is more transparent, it is carried out in a relatively short period and in a single stage. However, the length of time can be influenced by the large number of tenders that involve a significant consumption of human resources for evaluating the tenders received.

The restricted procedure can add value due to the limitation of those operators with a high level of expertise in the field, while at the same time it is more difficult to maintain transparency and avoid possible remedies.

The negotiated procedure is an exceptional procedure and can only be done with a solid justification of the special circumstances that have been taken into account.

Regarding the place where the procurement add will be published and whose legal norms it is subject to, it is necessary to compare the estimated budget with the thresholds established by Directive 2004/18 / EC. If the estimated value is higher, then the publication in the Official Journal of the European Union is mandatory.

The Tender Book is a document which is very important for the procurement, where there are summarized the objective of the procurement, the requirements necessary to be achieved and the awarding criterion. It is recommended that the Tender Book should be issued by a person having knowledge in the area of the procurement which is going to be achieved. The awarding criterion must be chosen carefully, without being discriminatory.

The awarding criterion must not limit the participation of operators in any way, as the use of only the lowest price criterion has a direct impact on the quality of the services to be provided, according to the authors.

All the necessary works must be mentioned in the Tender Book; its subsequent modification can lead to additional expenses and sometimes to the resumption of the tender. The Tender Book must comply with national standards and use a common technical specification that does not limit the participation of operators in all EU Member States. The publication notice must comply with all legislative provisions. (Law no. 98/2016)

After publication of the tender documentation, a reasonable time must be given to the economic agents to formulate their tender. Granting an unjustified short term is a deliberate limitation of competition, fact which can be sanctioned. Directive 2004/18 / EC sets the minimum time limits for each procedure that must be followed. During this time, the tenderers can request information regarding the procedure. Written communication with them is recommended to avoid suspicions of fraud. The requests of a tenderer, as well as the response of the Contracting Authority must be visible for any interested tenderer.

The place and date of tender's submission are set within the publication notice. The Evaluation Committee organizes a tender opening session and verifies that the selection criteria defined during the planning stage are complied with. The selection must be objective, applying the same judgment to all economic operators.

Abusive elimination of some tenderers or acceptance of tenderers who do not meet the selection criteria are situations that lead to the initiation of legal proceedings, as well as failure to comply with the deadlines set within the procurement schedule.

Within the selection process, a dynamic analysis was performed that quantifies the risk threshold. This degree of risk was determined to show the influence on the whole procedure, as well as the possibility of receiving tenders with significantly lower prices.

Table 1. Quantification of the risk degree of the selection stage

\begin{tabular}{|c|c|c|c|c|c|c|}
\hline \multirow[b]{2}{*}{ No } & \multirow[b]{2}{*}{ Reason } & \multicolumn{5}{|c|}{ Risk scale } \\
\hline & & $\begin{array}{c}\text { 1-very } \\
\text { low }\end{array}$ & $\begin{array}{c}2- \\
\text { low }\end{array}$ & \begin{tabular}{|c|}
$3-$ \\
average
\end{tabular} & $\begin{array}{l}\text { 4-high } \\
\text { risk }\end{array}$ & $\begin{array}{l}\text { 5- very high } \\
\text { risk }\end{array}$ \\
\hline 1 & The understanding of the need by the Procurement Department & & & & 4 & \\
\hline 2 & Definition of a realistic budget & & & & & 5 \\
\hline 3 & $\begin{array}{l}\text { Performance of the procedure for market consultation (testing the knowledge from } \\
\text { the tender book) }\end{array}$ & & & 3 & & \\
\hline 4 & Establishing the object of the contract & & & & & 5 \\
\hline 5 & Performance of a calendar (taking into consideration all unforeseen situations) & & & & 4 & \\
\hline 6 & Appointment of an Evaluation Committee (avoiding conflicts of interest) & & & & 4 & \\
\hline
\end{tabular}




\begin{tabular}{|c|c|c|c|c|c|c|}
\hline \multirow[b]{2}{*}{ No } & \multirow[b]{2}{*}{ Reason } & \multicolumn{5}{|c|}{ Risk scale } \\
\hline & & $\begin{array}{l}1 \text {-very } \\
\text { low }\end{array}$ & $\begin{array}{l}2- \\
\text { low }\end{array}$ & \begin{tabular}{|c|c|c|}
$3-$ & -1 \\
average
\end{tabular} & $\begin{array}{l}\text { 4-high } \\
\text { risk }\end{array}$ & $\begin{array}{l}\text { 5- very high } \\
\text { risk }\end{array}$ \\
\hline 7 & Performance of the entire documentation necessary for the procurement & & & 3 & & \\
\hline 8 & Choosing the optimum procedure & & & & 4 & \\
\hline 9 & Avoiding discriminatory or disproportionate requirements & & & & & 5 \\
\hline 10 & \begin{tabular}{|l} 
Comparing the requirements and price with other similar tenders \\
\end{tabular} & & & 3 & & \\
\hline 11 & Establishing the awarding criterion and its weight & & & & & 5 \\
\hline 12 & Issuing a clear and concise Tender Book & & & & & 5 \\
\hline 13 & $\begin{array}{l}\text { Publication of a participation notice without complying with the legislative } \\
\text { regulations }\end{array}$ & & & & & 5 \\
\hline 14 & Short terms granted to the economic operators in order to submit the tender & & & & & 5 \\
\hline 15 & Request of unjustifiably high participation guarantees as compared to the purchase & & & & & 5 \\
\hline 16 & Differentiated treatment in the tender selection stage & & & & & 5 \\
\hline & RISK DEGREE OF THE PROCEDURE & & & $4,4-\mathrm{H}$ & h risk & \\
\hline
\end{tabular}

Source: Issued by the author

It can be seen that a high level of risk has been determined during the selection stage, any failure to observe a stage can lead to significant financial corrections or costly and long-term processes. The evaluation process is based solely on verifying compliance with the requirements defined during the planning and preparation phase of the procurement.

\subsection{Evaluation process} the tender.

The evaluation method chosen during the planning stage must be applied to determine the winner of

The most used method of evaluation is the criterion of the lowest price because it is a transparent and difficult to challenge. But does the best price offer the best quality? Combined methods of evaluation are also met in practice, respectively experience criteria in a certain proportion corroborated with the lowest price.

However, what does happen when the contracting authority receives one or more tenders considered "tenders with abnormally low price"? This possibility had to be considered during the planning stage.

A definition of the abnormally low price offers is given by the World Bank (2016) in a thematic paper that addresses the same problem as the one presented by the authors in the present scientific endeavor. The translation of the definition is as follows: "An abnormally low tender / proposal is one in which the tender price / the tender, in combination with other elements of the tender / proposal, is so low that it raises important concerns about the tenderer / the tenderer's ability to execute the contract at the respective price level".

In this situation, the Contracting Authority is bound to ask the economic operator concerned for an economic justification of the tender in order to ensure that they benefit from certain special conditions. The special condition's category includes government aids, innovative technologies or any other conditions that allow the operator to provide the service at the mentioned price.

Depending on the formulated response, the Contracting Authority through the Evaluation Committee determines whether the tender is accepted or rejected.

At the same time, there is the possibility of making a mistake in the Tender Book that prevents the Tenderer from understanding the complexity and extent of the services purchased or just the misinterpretation of the economic operator.

The clarifications received by the authority should not bring significant changes to elements such as the price offered or the quality of services (European Commission, 2015). Equal treatment for all Tenderers must be complied with in the clarifications.

The decision of the Evaluation Committee must be supported by a complete report describing all the elements that have been taken into account for issuing the chosen decision.

A scheme indicated to be used by the Contracting Authorities to analyze the tenders with abnormally low price is presented in the World Bank's paper. This scheme was taken over by the author and processed in Figure 3.

Five main objectives which must be complied with are defined: identification, clarification, justification, verification and decision. 

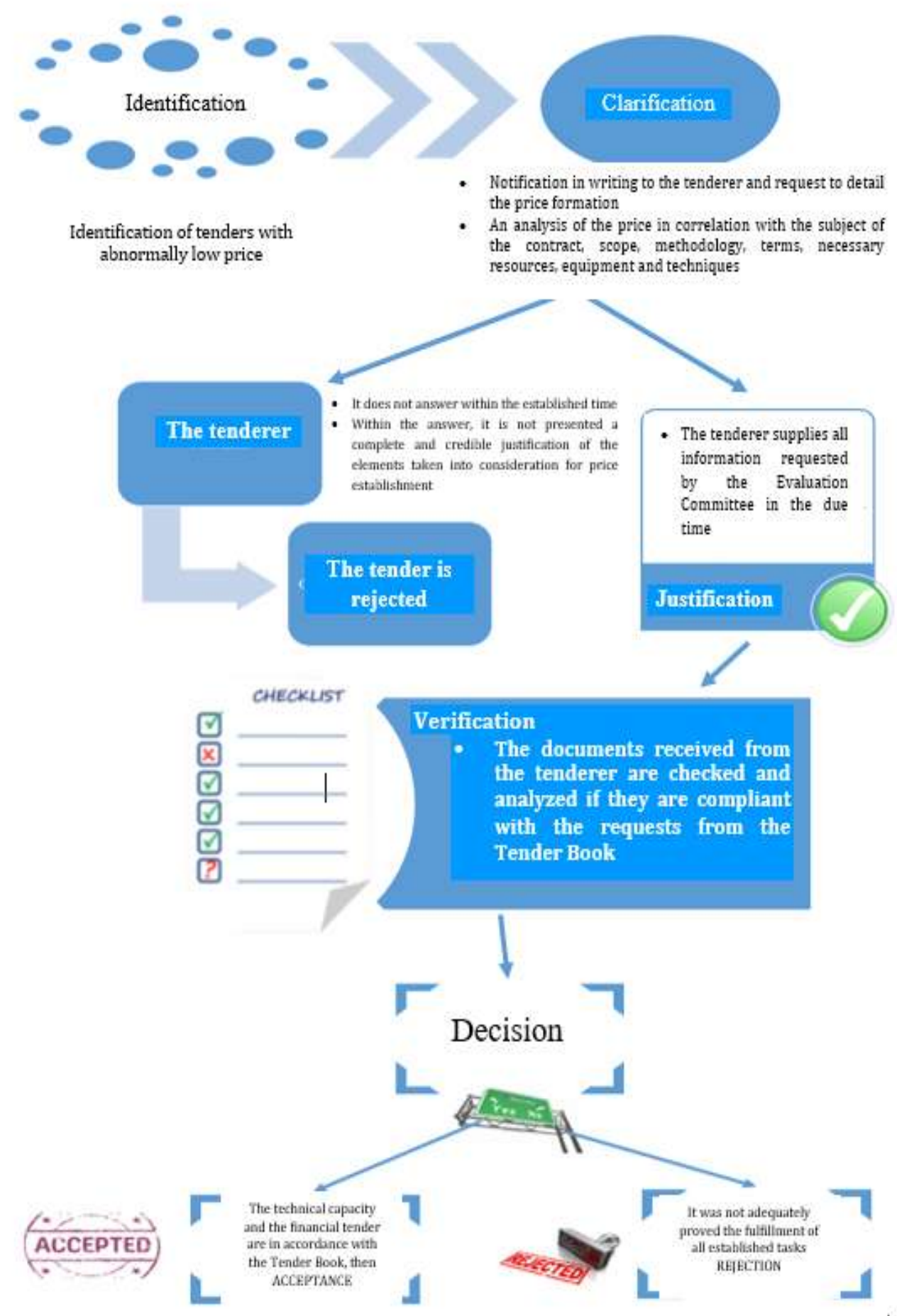

Figure 3. Procedure to be followed following to receiving a tender with abnormally low price Source: Processed by the author, based on the Guide published by the World Bank

After the evaluation process is completed, the Contracting Authority informs all economic operators participating in the procedure about its outcome. If no appeals have been registered after the expiration of the legal term, the contract can be signed.

Having the contract concluded, the two parties must contribute to its achievement in good conditions. The provider must provide the services for which it was contracted (Chicot and Matt, 2018) within the terms assumed and at the requested quality. The Contracting Authority must supervise the execution of the contract and respect its role established in the contract.

After the conclusion of the contract, the results of the contract will be evaluated by comparing it with the initial needs. The Guide prepared by the European Commission specifies that the Contracting Authority should be able to answer the questions presented in Figure 4. 
Figure 4. Survey which must be completed by the Contracting Authority at contract's finalization Source: Processed by the author based on the Guide issued by the European Commission.

The risk was determined also for the evaluation process. If the conditions set in the planning stage are not maintained, it results a very high risk. As stated by the author in the beginning of the paper, if a good planning is performed in the selection part, the risks from the evaluation stage are considerably reduced. The risk scale was presented in Table 2 .

Table 2. Quantification of the risk degree of the evaluation stage

\begin{tabular}{|c|c|c|c|c|c|c|}
\hline \multirow{2}{*}{$\begin{array}{l}\mathbf{N} \\
\mathbf{o}\end{array}$} & \multirow[b]{2}{*}{ Reason } & \multicolumn{5}{|c|}{ Risk scale } \\
\hline & & $\begin{array}{l}\text { 1-Very } \\
\text { low }\end{array}$ & $\begin{array}{l}2- \\
\text { Low }\end{array}$ & $\begin{array}{c}\text { 3- } \\
\text { Average }\end{array}$ & $\begin{array}{l}\text { 4- High } \\
\text { risk }\end{array}$ & $\begin{array}{l}\text { 5- Very high } \\
\text { risk }\end{array}$ \\
\hline 1 & Changing the awarding criteria within the evaluation process & & & & & 5 \\
\hline 2 & Equal treatment for all tenderers & & & & & 5 \\
\hline 3 & Significant change of the tenders during the evaluation & & & & & 5 \\
\hline 4 & $\begin{array}{l}\text { Existence of undeclared conflicts of interests during selection } \\
\text { phase }\end{array}$ & & & & & 5 \\
\hline 5 & $\begin{array}{l}\text { Rejection of tenders with abnormally low price without requesting } \\
\text { clarifications }\end{array}$ & & & & & 5 \\
\hline 6 & Modifications of technical specifications & & & & 4 & \\
\hline 7 & Negotiation of the price with the tenderer declared winner & & & & 4 & \\
\hline & RISK DEGREE OF THE PROCEDURE & \multicolumn{5}{|c|}{ 4,71- Very high risk } \\
\hline
\end{tabular}

\section{Empirical analysis of audit services procurement for the European projects in the year 2019}

As in the first part of the paper we have presented all the measures that the Contracting Authority can take to avoid altering the quality of the services and how to manage the tenders with abnormally low price within this section, the analysis will be performed from the tenderer's perspective.

Let's suppose we are an auditor with three years' experience in auditing projects with nonreimbursable financing, with a portfolio of more than three works contracted through Public Procurement.

The annual turnover is achieved in proportion of $40 \%$ from statutory audit contracts purchased by public tender and 60\% from European funds' auditors, also by public tender.

We will focus in this chapter on justifying a reasonable price for auditing a project from European funds, taking into account the provisions established by the Chamber of Financial Auditors of Romania (CAFR).

According to the CAFR decision no. 52/2013, the minimum number of hours for a financial audit mission based on agreed procedures (ISRS 4400) applicable to projects funded from European funds for a funding request is 105 hours (approximately 13 days).

The fixed CAFR membership fee is 162 euro/ year to which the variable membership fee of $0.8 \%$ is added, if the turnover is between 10,400 euro and 42,000 euro as we considered in our example. We suppose we carry out 10 works with similar values of auditing European funds.

The salary expenses with at least one person must be covered, as well as the expenses with travel, accommodation, insurance and consumables.

We have developed two scenarios:

The first scenario represents the maximum version in which the auditor must bear the travel and accommodation expenses. 
Table 3. The maximum variant of expenses which must be borne by the auditor

\begin{tabular}{|c|c|c|c|c|}
\hline No & Expense & $\begin{array}{c}\text { Amount } \\
\text { (euro) }\end{array}$ & $\begin{array}{l}\text { Amount assigned to the } \\
\text { procurement contract }\end{array}$ & $\begin{array}{c}\text { Observations (arbitrary exchange rate } 1 \\
\text { euro=4.8 lei) }\end{array}$ \\
\hline 1 & Monthly salary expenses & 910 & $\begin{array}{l}394 \text { (13 days out of } 30 \text { days of the } \\
\text { month) }\end{array}$ & Reported to a net salary of 516 euro \\
\hline 2 & $\begin{array}{|lr|}\text { Expenses for monthly fixed } \\
\text { membership fee to CAFR (162 } \\
\text { euro per year } / 12 \\
\text { months*60\%) }\end{array}$ & 10 & 4 euro (10 euro/30 days*13 days) & $\begin{array}{c}\text { Reported to a yearly membership fee of } 162 \\
\text { euro/year }\end{array}$ \\
\hline 3 & \begin{tabular}{|l|l|}
$\begin{array}{l}\text { Monthly expenses with } \\
\text { consumables }\end{array}$ \\
\end{tabular} & 106 & 53 euro & Printer cartridge, stationery, etc. \\
\hline 4 & $\begin{array}{l}\text { Travel expenses }-2 \text { round } \\
\text { trips (signing the contract } \\
\text { and analysis of documents for } \\
\text { the application) }\end{array}$ & 80 & 80 euro & $\begin{array}{l}\text { We consider the distance to the contracting } \\
\text { authority of maximum } \\
\qquad 200 \mathrm{~km}\end{array}$ \\
\hline 5 & $\begin{array}{l}\text { Accommodation expenses (13 } \\
\text { days) }\end{array}$ & 270 & 270 euro & \\
\hline 6 & $\begin{array}{l}\text { Monthly expenses with } \\
\text { variable membership fee to } \\
\text { CAFR }(0.8 \% \text { of } 42.000 / 12 \\
\text { months*60\%) }\end{array}$ & 17 & 7 euro ( 17 euro $/ 30$ days $* 13$ days) & \\
\hline 7 & Yearly insurance expenses & 42 & $\begin{array}{l}1 \text { euro (reported to the number of } \\
\text { days and weighted with } 60 \% \text { as it } \\
\text { represents the percentage of this } \\
\text { type of purchase) }\end{array}$ & \\
\hline 8 & Profit margin & $5 \%$ & 41 euro & \\
\hline 9 & $\begin{array}{l}\text { Tax on income for } \\
\text { micro }\end{array}$ & $1 \%$ & 9 euro & $\begin{array}{l}\text { The tax on dividends was not taken into } \\
\text { consideration. }\end{array}$ \\
\hline \multicolumn{3}{|c|}{ TOTAL PRICE/APPLICATION FOR FINANCING } & 859 & \\
\hline
\end{tabular}

Within the second scenario we have eliminated the accommodation and travel expenses, considering that the audit takes place in the locality of residence of the auditor.

Table 4. Minimum variant of expenses which must be borne by the auditor

\begin{tabular}{|c|c|c|c|c|}
\hline $\begin{array}{l}\mathbf{N} \\
\mathbf{o}\end{array}$ & Expense & $\begin{array}{l}\text { Amount } \\
\text { (lei) }\end{array}$ & $\begin{array}{l}\text { Amount awarded to the } \\
\text { procurement contract }\end{array}$ & $\begin{array}{c}\text { Observations (arbitrary exchange rate } 1 \\
\text { euro }=4.8 \text { lei) }\end{array}$ \\
\hline 1 & Monthly salary expenses & 910 & $\begin{array}{c}394 \text { (13 days out of } 30 \text { days of the } \\
\text { month) }\end{array}$ & Reported to a net salary of 516 euro \\
\hline 2 & \begin{tabular}{|l|} 
Expenses for monthly fixed \\
membership fee to CAFR $(162$ \\
per year / 12 months * 60\%)
\end{tabular} & 10 & 4 euro (10 euro/30 days*13 days) & $\begin{array}{l}\text { Reported to a yearly membership fee of } 162 \\
\text { euro/year }\end{array}$ \\
\hline 3 & \begin{tabular}{|l}
$\begin{array}{l}\text { Monthly expenses with } \\
\text { consumables }\end{array}$ \\
\end{tabular} & 106 & 53 euro & Printer cartridge, stationery, etc. \\
\hline 4 & $\begin{array}{l}\text { Monthly expenses with variable } \\
\text { membership fee to CAFR }(0.8 \% \\
\text { of } 42,000 / 12 \text { months } * 60 \%)\end{array}$ & 17 & 7 euro (17 euro/30 days $* 13$ days) & \\
\hline 5 & Yearly insurance expenses & 42 & $\begin{array}{l}1 \text { euro (reported to the number of } \\
\text { days and weighted with } 60 \% \text { as it } \\
\text { represents the percentage of this } \\
\text { type of purchase) }\end{array}$ & \\
\hline 6 & Profit margin & $5 \%$ & 23 euro & \\
\hline 7 & $\begin{array}{l}\text { Tax on income for } \\
\text { micro }\end{array}$ & $1 \%$ & 5 euro & $\begin{array}{l}\text { The tax on dividends was not taken into } \\
\text { consideration. }\end{array}$ \\
\hline \multicolumn{3}{|c|}{ TOTAL PRICE/APPLICATION FOR FINANCING } & 487 & \\
\hline
\end{tabular}

Source: Issued by the author

Starting from these estimations, we have performed an analysis of the prices used for awarded contracts similar to those analyzed, with the help of the information published on SICAP Platform and licitatiapublice.ro. 


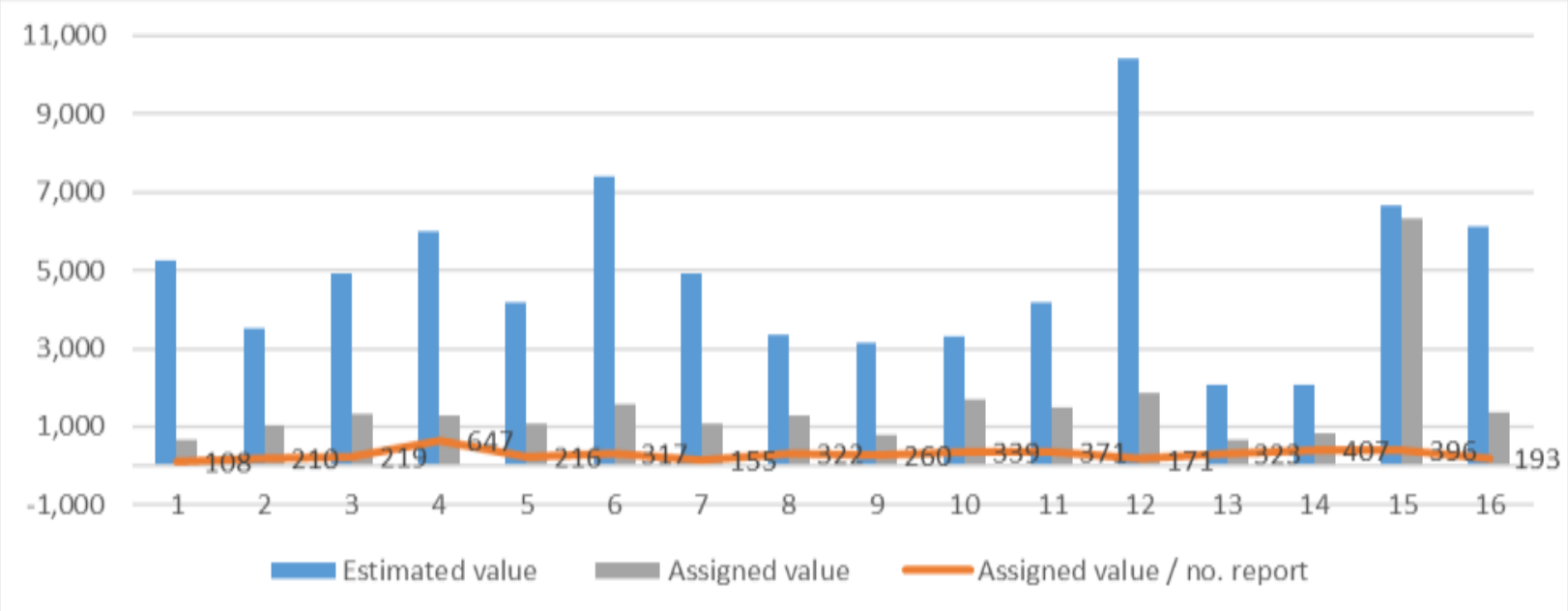

Figure 5. Market analysis for awarding audit service procurement from European Funds, $1^{\text {st }}$ semester 2019

Source: Processed by the author, based on the information from SICAP and licitatiapublice.ro Platforms

In these conditions, how can they compete with the prices applied on the market and how can they justify the price offered to the Contracting Authority?

We observe an exaggerated difference between the estimated prices and the assigned prices, being mainly in the range between 12 and $35 \%$ of the estimated value.

We would like to mention that practicing a price below the level set by the professional body will attract the auditor's sanctioning during the verification visit.

Taking into account the number of hours necessary for carrying out the mission and reporting to the assigned value the number of reports to be completed, it results a cost per hour between 5 and 29 lei.

The cost indicated by CAFR ranges between 90 and 99 lei per hour.

In these conditions, as a Tenderer, what can you do to cope with the competition on the market, considering that this type of purchases represents $60 \%$ of the turnover?

We have analyzed the possibilities of justification of the Tenderers who use abnormally low prices and we have reached a single conclusion: it can only be justified by reducing the effective working time / demand and reporting the salary to the minimum salary on the economy.

Table 5. Justification of low prices

\begin{tabular}{|c|c|c|c|c|}
\hline No. & Expense & $\begin{array}{c}\text { Amount } \\
\text { (euro) }\end{array}$ & $\begin{array}{l}\text { Amount assigned to the } \\
\text { procurement contract }\end{array}$ & $\begin{array}{c}\text { Observations (arbitrary exchange rate } 1 \\
\text { euro }=4.8 \text { lei) }\end{array}$ \\
\hline 1 & Monthly salary expenses & 443 & $\begin{array}{l}118 \text { (8 days out of } 30 \text { of the } \\
\text { month) }\end{array}$ & Reported to a minimum salary of 433 euro. \\
\hline 2 & $\begin{array}{l}\text { Expenses for monthly fixed } \\
\text { membership fee to CAFR }(162 \\
\text { per year } / 12 \text { months*60\%) }\end{array}$ & 8 & $\begin{array}{c}2 \text { euro (8 euro/30 days } * 8 \\
\text { days) }\end{array}$ & $\begin{array}{l}\text { Reported to a yearly membership fee of } 162 \\
\text { euro/year }\end{array}$ \\
\hline 3 & $\begin{array}{l}\text { Monthly expenses with } \\
\text { consumables }\end{array}$ & 104 & 52 euro & Printer cartridge, stationery, etc. \\
\hline 4 & $\begin{array}{l}\text { Monthly expenses with variable } \\
\text { membership fee to CAFR }(0.8 \% \\
\text { of } 42,000 / 12 \text { months } 60 \%)\end{array}$ & 17 & $\begin{array}{l}4 \text { euro (17 euro/30 days } * 8 \\
\text { days) }\end{array}$ & \\
\hline 5 & Yearly insurance expenses & 42 & $\begin{array}{c}1 \text { euro (reported to the } \\
\text { number of days and weighted } \\
\text { with } 60 \% \text {, as it represents the } \\
\text { percentage of this type of } \\
\text { purchase }\end{array}$ & \\
\hline 6 & Profit margin & $5 \%$ & 9 & \\
\hline 7 & $\begin{array}{l}\text { Tax on income for } \\
\text { micro }\end{array}$ & $1 \%$ & 2 & $\begin{array}{l}\text { The tax on dividends was not taken into } \\
\text { consideration }\end{array}$ \\
\hline \multicolumn{2}{|c|}{$\begin{array}{l}\text { TOTAL PRICE/APPLICATION FOR } \\
\text { FINANCING }\end{array}$} & & 189 & \\
\hline \multicolumn{3}{|c|}{ PRICE LEI/ HOUR } & 3 & $\begin{array}{l}\text { The total number of hours is } 64 \text { ( } 8 \text { days } x 8 \\
\text { hours) }\end{array}$ \\
\hline
\end{tabular}

Source: Issued by the author

In these conditions, the quality of the audit service is certainly reduced. The auditor will decrease the attention paid directly in proportion to the decrease in working time. 
What should the auditor taken as example in this study do? Should he/she reduce the number of hours, accepting the corresponding risks and compete, or should he/she give up $60 \%$ of turnover and look for other types of contracts?

\section{Conclusions}

Following the analysis from both the Contracting Authority and the Tenderer's perspectives, it was demonstrated that both can influence the receipt of abnormally low financial tenders related to market prices.

From the perspective of the Contracting Authority, there is the possibility of omitting certain aspects that have determined the misunderstanding of the contract size and it is necessary to request clarification and not to downgrade the tender on the spot.

On the contrary, the economic operator either does not fully understand the requirements requested by the Contracting Authority, or it struggles to face the pressing competition, no matter the costs.

Within procurement, it is important to ensure the fulfillment of the need for which the procurement was requested, within the deadline and within the qualitative parameters established in the technical documentation.

\section{Acknowledgements \\ „This work is supported by the project ANTREPRENORDOC, in the framework of Human Resources Development Operational Programme 2014-2020, financed from the European Social Fund under the contract number 36355/23.05.2019 HRD OP /380/6/13 - SMIS Code: $123847 . "$}

\section{References}

1. Booth, L. (2015). "Public Procurement." Briefing Paper, No. 6029. House of Commons

2. Chicot, J., \& Matt, M. (2018). Public procurement of innovation: A review of rationales, designs, and contributions to grand challenges. Science and Public Policy, 45, 480-492. https://doi.org/10.1093/scipol/scy012..

3. Crown Commercial Services (2016). "A Brief Guide to the 2014 EU Public Procurement Directives," Crown Commercial Services, Available from: https://www.gov.uk/government/uploads/system/uploads/attachment_data/file/560261/Brief_Guide_to_the 2014 Directives_Oct_16.pdf (accessed on 19.11.2019).

4. Edler, J., Ruhland, S., Hafner, S., Rigby, J., Georghiou, L., Hommen, L., Rolfstam, M., Edquist, C., Tsipouri, L., and Papadakou, M. (2006). Innovation and Public Procurement. Review of Issues at Stake. Study for the European Commission (No ENTR/03/24). Fraunhofer Institute for Systems and Innovation Research.

5. European Commission (2015), Guidance to help public procurement principals on avoiding the most common errors in projects financed by European Structural and Investment Funds, Luxembourg

6. Kassa Woldesenbet \& Ian Worthington (2019) Public Procurement and Small Businesses: Estranged or Engaged?, Journal of Small Business Management, 57:4, 1661-1675, DOI: 10.1111/jsbm.12442

7. Rolfstam M., Philips W., Bakker E. (2013), Public procurement and innovation: The role of institutions, Edward Elgar, Northampton

8. Vargo S.L., Koskela-Huotari K., Baron S., Edvardsson B., Reynoso J., Colurcio M. (2017), A systems perspective on markets - Toward a research agenda Journal of Business Research, 79, pp. 260-268

9. World Bank (2016), Abnormally Low Bids and Proposals Guide to the identification and treatment of Abnormally Low Bids and Proposals, Washington

10. ${ }^{* * *}$ Commercial platform for monitoring the public tenders, http://licitatiapublica.ro accessed on the date of 21.11.2019.

11. ${ }^{* * *}$ Decision no. 52/2013 on the approval of the Norms on establishing a minimum average number of hours for the finalization of a mission based on convened procedures (ISRS 4400) available on cafr.ro website

12. *** Directive $2004 / 18 / E C$

13. *** Law no. 98/2016 on Public Procurement

14. ${ }^{* * *}$ Public tender's Platform, https://sicap-prod.e-licitatie.ro/pub, accessed on the date of 21.11.2019.

15. ***Site of the Professional Body in audit area, http://cafr.ro, accessed on the date of 20.11.2019.

16. ***Website of the National Institute of Statistics, http://innse.ro, accessed on the date of 20.11.2019. 